\title{
New trends on childhood nutrition
}

\author{
Luigi Memo ${ }^{1 *}$, Sonia Viale ${ }^{2}$ \\ From XX National Congress of the Italian Society of Neonatology \\ Rome, Italy. 9-11 October 2014
}

\section{Background}

An optimal growth is the first objective of feeding during infancy. Recent trials demonstrated that environmental and nutritional influences during critical periods in development, can have permanent effects on an individual's predisposition to diseases in adulthood.

\section{Materials and methods}

This review summarises the studies on the associations between nutrition during pregnancy and infancy with illnesses later in life.

\section{Results}

Maternal nutrition during gestation is important for metabolic programming. Individuals born small for gestational age or prematurely have higher rates of insulin resistance, confirming an association between birth weight and later diabetes, heart disease and obesity [1-3]. High-protein intake during early childhood is associated with obesity, while breastfeeding and timely introduction of complementary foods were shown to protect against obesity in adulthood. Direct benefits of exclusive breastfeeding to the infant's nutrition, gastrointestinal function, host defence and psychological well-being are known in literature. Although evidence is often inconclusive, breastfeeding may be associated with long term benefits such as lower risk of acute illnesses, obesity, cancer, adult coronary heart disease, allergic conditions, type 1 diabetes and inflammatory bowel disease [4].The ESPGHAN recommends complementary foods introduction between 17 and 26 weeks of age [5,6]. Early introduction has been associated with an increased risk of obesity $[7,8]$; feeding cereals to infants at high risk for type 1 diabetes or celiac disease before 3 months of age may increase the risk of autoimmunity. Later introduction of complementary foods may be associated with adverse effects: decreased growth, iron deficiency, development of atopy and celiac

${ }^{1}$ Paediatric Department, San Martino Hospital, Belluno, Italy

Full list of author information is available at the end of the article disease or type 1 diabetes. Primary prevention of allergic disease through nutritional interventions has changed [9]. Avoidance diets during pregnancy and lactation are not recommended. Exclusive breast-feeding for at least 4 and up to 6 months is endorsed. Hydrolyzed formula prevents allergic disease and cow's milk allergy in high-risk infants who cannot be exclusively breast-fed. Complementary foods can be introduced between 4 and 6 months of age even for high risk infants. The important role of Vitamin D during pregnancy and infancy is still supported by literature $[10,11]$. Several recent clinical trials have been conducted to evaluate the effect of supplementation of Docosahexaenoic acid (DHA):it may improve neurodevelopmental outcome in very preterm infants and visual acuity for all infants [12].

\section{Conclusions}

Controlled trials of early nutritional interventions with long-term outcomes are still lacking. Nonetheless, there is ample circumstantial evidence to support clinical efforts to optimize nutrition during gestation, infancy, and early childhood.

\section{Authors' details}

${ }^{1}$ Paediatric Department, San Martino Hospital, Belluno, Italy. ${ }^{2}$ Department of Woman and Child Health, Padua University, Padua, Italy.

Published: 9 October 2014

\section{References}

1. Fraser A, Tilling K, Macdonald-Wallis C, Sattar N, Brion MJ, Benfield L, Ness A, Deanfield J, Hingorani A, Nelson SM, Smith GD, Lawlor DA: Association of maternal weight gain in pregnancy with offspring obesity and metabolic and vascular traits in childhood. Circulation 2010, 121(23):2557-2567.

2. Taveras EM, Rifas-Shiman SL, Sherry B, Oken E, Haines J, Kleinman K, RichEdwards JW, Gillman MW: Crossing growth percentiles in infancy and risk of obesity in childhood. Arch Pediatr Adolesc Med 2011, 165:993.

3. Baird J, Fisher D, Lucas P, Kleijnen J, Roberts H, Law C: Being big or growing fast: systematic review of size and growth in infancy and later obesity. BMJ 2005, 331(7522):929.

4. Kramer MS, Kakuma R: Optimal duration of exclusive breastfeeding. Cochrane Database Syst Rev 2012, , 8: CD003517. 
5. Agostoni C, Decsi T, Fewtrell M, Goulet O, Koletzko B, Michaelsen KF, Moreno L, Puntis J, Rigo J, Shamir R, Szajewska H, Turck D, van

Goudoever J: Complementary feeding: a commentary by the ESPGHAN Committee on Nutrition. J Pediatr Gastroenterol Nutr 2008, 46(1):99-110.

6. Jonsdottir OH, Thorsdottir I, Hibberd PL, Fewtrell MS, Wells JC, Palsson Gl, Lucas A, Gunnlaugsson G, Kleinman RE: Timing of the introduction of complementary foods in infancy: a randomized controlled trial. Pediatrics 2012, 130:1038.

7. Lin SL, Leung GM, Lam TH, Schooling CM: Timing of solid food introduction and obesity: Hong Kong's "children of 1997" birth cohort. Pediatrics 2013, 131:e1459.

8. Huh SY, Rifas-Shiman SL, Taveras EM, Oken E, Gillman MW: Timing of solid food introduction and risk of obesity in preschool-aged children. Pediatrics 2011, 127:e544.

9. Fleischer DM, Spergel JM, Assa'ad AH, Pongracic JA: Primary prevention of allergic disease through nutritional intervention. J Allergy Clin Immunol Pact 2013, 1(1):29-36.

10. Misra M, Pacaud D, Petryk A, Collett-Solberg PF, Kappy M: Vitamin D deficiency in children and its management: review of current knowledge and recommendations. Pediatrics 2008, 122(2):398-417.

11. Mansbach JM, Ginde AA, Camargo CA Jr: Serum 25-hydroxyvitamin D levels among US children aged 1 to 11 years: do children need more vitamin D? Pediatrics 2009, 124:1404.

12. Schulzke SM, Patole SK, Simmer K: Long-chain polyunsaturated fatty acid supplementation in preterm infants. Cochrane Database Syst Rev 2011, , 2: CD000375.

doi:10.1186/1824-7288-40-S2-A18

Cite this article as: Memo and Viale: New trends on childhood nutrition. Italian Journal of Pediatrics 2014 40(Suppl 2):A18.

\section{Submit your next manuscript to BioMed Central} and take full advantage of:

- Convenient online submission

- Thorough peer review

- No space constraints or color figure charges

- Immediate publication on acceptance

- Inclusion in PubMed, CAS, Scopus and Google Scholar

- Research which is freely available for redistribution

Submit your manuscript at www.biomedcentral.com/submit
Biomed Central 